\title{
El partido Republicano Liberal Demócrata, 1931-1936. Aspectos ideológicos y programáticos
}

\author{
LUIS ÍNIGO FERNÁNDEZ
}

\section{INTRODUCCIÓN}

Como alguna vez recuerdan sus propios militantes, el Partido Republicano Liberal Demócrata no es sino el Partido Reformista de los tiempos de la monarquía alfonsina, que ha cambiado de nombre para adecuarse al contexto político de la Segunda República. Este cambio de denominación tuvo lugar en un acto celebrado en el Hotel Palace de Madrid el 24 de mayo de 1931. En él, Melquiades Alvarez, líder del partido desde su fundación en 1912, tenía la intención de definir la posición que éste venia a ocupar dentro del nuevo régimen. No pudo alcanzar su objetivo porque un desvanecimiento se lo impidió - contaba por entonces el veterano líder asturiano sesenta y siete años- pero sin duda lo hizo en los múltiples discursos que en los años siguientes tendría la ocasión de pronunciar y que constituyen la principal fuente de información acerca de la ideología del partido. En este trabajo intentaremos, precisamente, a partir de esas y otras fuentes, desentrañar los rasgos principales de esa ideología, asi como analizar su plasmación en forma de propuestas de soluciones concretas a las cuestiones principales que por entonces tenía planteadas el país, es decir, lo que habitualmente se denomina programa de un partido político. Por último, y basándonos en ambos aspectos, ideología y programa, trataremos de ubicar al Partido Republicano Liberal Demócrata dentro del espectro político de la Segunda República española.

Antes de abordar estos objetivos, sin embargo, realizaremos una breve sintesis de la trayectoria del melquiadismo antes de 1931, pues si habitualmente en todo estudio doctrinal de una fuerza política han de contemplarse las fuentes de las que bebe su ideología, tal análisis resulta aún más imprescindible en el caso de un partido como el que nos ocupa, que cuenta con una dilatada ejecutoria política previa. Sólo teniendo ésta en cuenta puede resultar posible comprender en su verdadera dimensión el 
significado doctrinal de los liberales demócratas en el contexto de la República.

\section{REPUBLICANOS Y REFORMISTAS}

La trayectoria política del melquiadismo nace como una rama desgajada del tronco común del republicanismo histórico, en el que convivían, compartiendo un mismo universo mental basado en la exaltación de la democracia, el progreso y la libertad, el racionalismo, el laicismo y la fe en la educación como herramienta de reforma social, sensibilidades muy diversas que habian hecho casi siempre imposible articular un programa y una táctica comunes. En efecto, los republicanos españoles deseaban un mundo parecido, pero discrepaban en la forma de conseguirlo. Unos se inclinaban más hacia la derecha; otros, hacia la izquierda. Para estos, el Estado debia conservar íntegras sus atribuciones; para aquellos, el federalismo era la solución al problema regional. Para los de este lado, el poder público no debía intervenir en la cuestión social; para los de aquél, sólo la intervención estatal podía atenuar las tensiones económicas. Ciertamente, los mismos republicanos eran conscientes de ello y habian hecho algún intento para superar sus divisiones crónicas, preparando así sus aparejos para aprovechar el viento favorable que, en forma de crisis del sistema de la Restauración, soplaba para las fuerzas que se situaban fuera de él. Pero del mismo modo que los intentos, se suceden los fracasos. Sólo un hecho positivo se derivó de ellos. Las ideas, al menos, se aclararon y sirvieron de base para la articulación de dos tendencias más o menos claras en el seno de los hijos de Marianne. A un lado quedaron los más revolucionarios, que habrian de agruparse en 1908 en torno a Alejandro Lerroux para formar el Partido Republicano Radical. Al otro, los más abiertos a transformar el régimen desde dentro. Estos, los llamados gubernamentales, serian los llamados a constituir bajo el liderazgo de prohombres como Gumersindo de Azcárate y Melquiades Alvarez, el que recibiría el nombre de Partido Republicano Reformista.

Esta fuerza política vio la luz del sol por vez primera en abril de 1912. Círculos Melquiadistas ya existían en Asturias desde la primera década del siglo, y en Salamanca rebullía de actividad desde 1910 una Agrupa-ción Republicana Gubernamental, cuyo secretario era el doctor Filiberto Villalobos, Ilamado a ocupar el Ministerio de Instrucción Pública en algunos gobiernos del segundo bienio de la República. Pero fue el día 7 de abril de 1912, en el Palacio de Industrias del Retiro madrileño, el momento preciso del parto del Partido Reformista. Con él nacían ya las ideas que no habrían 
de abandonarle durante más de veinte años de vida, formuladas entonces por Alvarez, tan amante de las frases altisonantes, casi con idénticas palabras a las que saldrian de sus labios en los años treinta. El partido nacía con una finalidad clara. Se proponia poner en práctica, con el apoyo de las capas medias urbanas y de los intelectuales herederos del krausismo, aquel programa que en la Europa más avanzada llevaban en sus carteras los partidos liberales. Saltaba a la arena de la lucha partidaria con la bandera de las reformas políticas, económicas y sociales que debían hacer de España un país moderno y socialmente justo, dirigido por un Estado laico y descentralizado.

Pero si las ideas estaban claras, y no se apartaban gran cosa de la tradición republicana, lo que habría de definir al reformismo en los años del crepúsculo de la Restauración sería su táctica, su posibilismo acerca de la cuestión del régimen. Desde 1913, muchos seguidores de Alvarez, convencidos de que, según la famosa sentencia de Azcárate, habian desaparecido los obstáculos tradicionales, y de que, por tanto, la Monarquía podia transformarse desde dentro, harán su razón de ser política del logro de ese objetivo. El 23 de octubre, en un histórico banquete en el Palace de Madrid, Alvarez proclamó el accidentalismo del partido: los reformistas gobernarían con la Monarquía si ésta aceptaba democratizarse, porque, en última instancia, lo esencial era la democracia y no el ropaje con el que ésta se vistiera.

Sobre el papel, la posición del partido parecia diáfana y precisa. En la práctica, su realización condujo a los reformistas a una especie de esquizofrenia política que, provocada por una doble atracción fatal hacia la izquierda y la derecha, hacia la República y hacia la Monarquía, no se resolvería nunca del todo, dando lugar a sucesivos bandazos tácticos que jalonarian la trayectoria del melquiadismo entre 1913 y 1923. Al principio, el camino parecía despejado. Si era cierto que el régimen se encontraba dirigido por una oligarquía caciquil que monopolizaba los aparatos del Estado, impidiendo el acceso al poder de los grupos sociales ajenos a ella, lo que cerraba el camino del reformismo hacia el gobierno, no lo era menos que los partidos dinásticos que servian de instrumento a esa oligarquía se estaban desmoronando por momentos, presa de banderías y de luchas intestinas crecientes. Este proceso -así lo dictaba la lógicadebería conducir al monarca a buscar un recambio entre las fuerzas moderadas de la izquierda, abriendo así paso a la democratización del régimen, que era el objetivo reformista. Pero lo que ocurrió, como es bien sabido, fue todo lo contrario. Los partidos dinásticos se descomponían, sí, pero a un ritmo muy lento, que el expediente de urgencia de los gabinetes de concentración ralentizaba aún más, y frente a tan pausada decadencia, 
el reformismo no hacía sino conservar una postura de ambigüedad calculada, que en el terreno electoral le conducía a alianzas simultáneas con la derecha y con la izquierda, oscilando entre republicanos y liberales. Este comportamiento, que podía ser presentado como un hecho puramente táctico que no llevaba aparejado una renuncia doctrinal, desgastaba a pesar de ello la imagen del partido sin llevarle a ningún resultado, pues los mecanismos electorales del régimen, en el cual las mayorías sólo podían ser construidas desde el poder, le impedían conseguir más allá de la decena de escaños.

Quizá por ello cuando, en 1917, explotaron las tensiones acumuladas en la sociedad española por obra de un régimen incapaz de hacer nada positivo por abrir un cauce pacífico hacia su resolución, y de una coyuntura especialmente favorable a su exacerbación, como era la creada por las repercusiones en el país de la Gran Guerra, el reformismo dio marcha atrás en sus postulados tácticos y abrazó de nuevo posiciones francamente republicanas. Llegó incluso más allá: figuró incluso en el bando revolucionario, es decir, al lado de los que presionaban desde fuera al régimen para forzar su democratización. Parecía una vuelta a los orígenes, pero se trataba de un espejismo. El fracaso terrible con que se cerró la experiencia revolucionaria, presa de sus propias contradicciones internas, indujo de nuevo al melquiadismo a retomar desde 1918 la táctica abandonada el año anterior, sólo que ahora con un matiz aún más derechista. Si antes había perseguido convertirse en la fuerza de izquierdas en el Parlamento de una hipotética Monarquía democratizada en la que el Partido Liberal ejercería como derecha, ahora perseguirá la alianza con el liberalismo dinástico, aceptando como rival político a los conservadores. Ciertamente, para sellar esa alianza, que fue su objetivo entre 1918 y 1922, exigirá de los liberales, primero, la superación de sus querellas intestinas, y, después, la depresión de sus métodos caciquiles y la asunción de un programa de reformas democráticas profundas. $Y$ así, en diciembre de 1922, la esperanza de los reformistas parece a punto de realizarse. El pacto con los liberales, que han aceptado lo esencial de las condiciones reformistas, queda sellado y el mismo rey se ha mostrado dispuesto a entregar el gobierno a García Prieto, cabeza visible de la alianza.

Pero se trata, una vez más, de un espejismo. Los liberales no son un partido comparable a sus homónimos europeos, partidos modernos, con un programa y una organización orientada hacia la captación de la opinión pública, sino la parte más presentable de un entramado oligárquico caciquil concebido para perpetuar en el poder a la oligarquia tradicional de terratenientes y financieros. $Y$ esta oligarquía no está dispuesta a pactar una transacción, por mínima que sea, que suponga sacrificar ni un ápice 
de sus privilegios, como no lo están tampoco la Iglesia y el Ejército, sus aliados seculares. Así, el proyecto reformista, no exento tampoco de contradicciones internas, nacidas de una organización de cuadros, sin masas de importancia, dotado de una débil democracia interna y con apoyos limitados a una fracción de la débil clase media y a los cenáculos de intelectuales progresistas, tenia que estrellarse contra su propia obcecación. Si la Monarquía podía de algún modo democratizarse, la tarea excedía en mucho las exiguas fuerzas de que disponía el reformismo.

El golpe de Estado del general Primo de Rivera vino a demostrarlo con creces. La oligarquía podía estar tranquila. Seguiria detentando el poder del que se creia acreedora exclusiva. Pero el precio fue demasiado alto. Los viejos partidos dinásticos, que le habían sido tan útiles, quedaron desarticulados por completo. El reformismo, que en el fondo habría resultado ser una solución transaccional no demasiado dañina para ella, sufrió un duro golpe al perder el apoyo más selecto de que disponía: el de los intelectuales, que abrazaron en masa posiciones más izquierdistas. $Y$ cuando el régimen militar volvió a dar paso a un gobierno civil, la Monarquia se encontró sin instrumentos de gobierno y sin apoyo político organizado. Melquiades Alvarez, junto a otros líderes monárquicos, va a intentar ofrecérselo a través de la fórmula constitucionalista. El fracaso de ésta abre las puertas a la República el 14 de abril de 1931. Para muchos españoles de matiz conservador, entre ellos el mismo Álvarez, que no tiene dificultades en volver a proclamarse republicano, es la ultima oportunidad. Si la República fracasa, será la hora de la revolución.

Definidas las principales coordenadas en las que se había movido el melquiadismo durante su trayectoria anterior a 1931, podemos ocuparnos ya de lo que es el verdadero objeto de este trabajo: el análisis de sus posiciones ideológicas y programáticas en el contexto de la Segunda República.

\section{ASPECTOS IDEOLÓGICOS}

La propia denominación adoptada por el partido en los primeros meses del régimen, contiene ya dos adjetivos de fuerte contenido ideológico que $\sin$ duda fueron escogidos por Álvarez - la propuesta del cambio de nombre del viejo reformismo la hizo él mismo en el Palace- con la intención de mostrar de forma visible cuáles eran las señas de identidad de su fuerza política. Liberalismo y democracia son, desde luego, dos rasgos que la definen, pero resulta evidente la necesidad de cuestionarse con qué contenidos concretos se identifican, pues no es necesario remontarse a los modernos estudios 
sobre lexicología política ${ }^{1}$ para asumir cuán diferentes significados pueden asociarse al mismo significante en función de los distintos contextos ideológicos, políticos y socioeconómicos en los que se muevan el emisor del mensaje y sus receptores. ¿Qué significan pues, liberal y demócrata en este caso?

El liberalismo ha de entenderse tanto en su vertiente económica como en su vertiente política. En el terreno económico, la posición del partido no ofrece dudas. Los liberal-demócratas se sitúan con claridad en defensa de un sistema que garantice un respeto absoluto por la propiedad y la iniciativa privadas, a las que consideran motores básicos del progreso social, y frente a un socialismo igualitario que aniquila ese progreso al matar lo que lo impulsa, el legítimo deseo de medrar: Mientras el trabajo no tenga una base ética -en palabras de Álvarez- serán el interés y el egoismo los creadores de riqueza ${ }^{2}$. La propiedad privada es, en última instancia, la base del orden social, tanto en lo que se refiere a los bienes de consumo como en lo referido a los medios de producción, pues el capital halla su legitimación en su origen, que no es otro que el trabajo acumulado a través del ahorro. La única excepción es la tierra, factor de producción que, como el agua, pertenece de alguna manera al conjunto de la sociedad y se hace por ello acreedora de un tratamiento jurídico especial, que permite la expropiación compensada por causa de necesidad superior aunque siempre para convertir lo expropiado en nueva propiedad privada del campesinado sin tierra. La propiedad estatal o colectiva no se admite bajo ningún concepto. En lo ecónomico traería, como hemos visto, la miseria, pues, privada de incentivos, la gente dejaría de trabajar; en lo político, el fin de la democracia, pues otorgaría al Estado un poder omnipotente que no dejaría sitio para la libertad.

De los argumentos anteriores se deriva un trágico corolario: la desigualdad de las fortunas, además de natural, es también deseable, ya que su existencia constituye un incentivo para que los que la padecen trabajen para mejorar su nivel de vida. Si la sociedad se nivela artificialmente, como pretende el socialismo, desaparecerá el incentivo y con él el progreso. Por ello no cabe aceptar como dogma político ...la supremacia proletaria, que altera fundamentalmente la jerarquia natural, en cuya virtud deben dominar siempre los más capaces... ${ }^{3}$. Tales afirmaciones, que parecen conducir a la

\footnotetext{
Véase, por ejemplo, Garcia Santos, J.F.: Léxico y politica de la Segunda República. Salamanca, Ediciones de la Universidad, 1980.

2 Discurso de Melquiades Álvarez en el Teatro de la Comedia de Madrid, 3 de enero de 1932, Ahora, 5 de enero de 1932.

3 Cuber, M.: Melquiades Álvarez. El orador, el hombre, el politico, sus ideales, su consecuencia, su integridad. Madrid, Reus, 1935, pág. 94.
} 
identificación de capacidad y riqueza, dejan en el paladar un regusto decimonónico que recuerda incluso las viejas y burdas justificaciones sociobiologistas, de cuño espenceriano, del capitalismo. No sería justo, sin embargo, ubicar aquí a los liberal-democrátas. Cuando recurren a estos argumentos se están refiriendo más bien a un futuro en el que la extensión universal de la cultura, obra del Estado, haya colocado a todos los ciudadanos en igual posición de partida, de forma que sean sólo el esfuerzo y la capacidad individual los factores del éxito y del fracaso, y no la ventaja económica heredada. Es, por tanto, el legado de Krause y no el de Spencer el que cabe adivinar en estas ideas.

Pero si al Estado se le concede un papel tan fundamental en la culturización de las masas, no ocurre lo mismo en la economía. Conscientes de vivir una época en la que el intervencionismo estatal ha alcanzado cotas desconocidas desde el triunfo del liberalismo, los melquiadistas defienden su reducción al mínimo posible. Cuber llega incluso a afirmar que ...una dolorosa experiencia nos ha demostrado que todo lo oficial es positivamente malo, y que el progreso de una nación se halla en razón inversa del número y extensión de sus leyes ${ }^{4}$. La función del Estado, por tanto, debe ser subsidiaria de la iniciativa individual; ha de completarla y socorrerla, pero nunca sustituirla. Se limitará a aquellas situaciones en las que exista una verdadera e indiscutible necesidad que los individuos, por sí solos, sean incapaces de satisfacer. Por ellos, aunque no se rechacen de plano, no se ve una buena solución en los subsidios estatales, que tienden a crear en la sociedad una mentalidad parasitaria, muy perjudicial para el progreso ${ }^{5}$. El ideal será un Estado reducido a una maquinaria lo más simple y barata posible, limitada casi en exclusiva a velar por la educación, la justicia y el orden público, aunque, eso sí, por medio de fórmulas jurídicas compatibles con la libertad. Las medidas de excepción, como la famosa Ley de defensa de la República, son rechazadas por el partido, que la ve como ...un recurso supremo defensivo puesto en manos del Gobierno sólo transitoriamente y mientras la nación afirma sus nuevas instituciones constitucionales ${ }^{6}$.

El liberalismo, por tanto, tiene también para los melquiadistas una lectura política, que va a manifestarse con claridad diáfana en el contenido

4 CUBer, M.: Melquiades Álvarez..., págs. 163-164.

...no con subvenciones ni con subsidios temporales, que tienen más de limosna del poder público que de ayuda racional y práctica, el problema hullero de Asturias, que es de consumo principalmente, se habrá resuelto cuando cese la crisis de la metalurgia, de las obras públicas, de los ferrocarriles, de las construcciones urbanas... ("A la opinión asturiana. El manifiesto electoral del Partido Republicano Liberal Demócrata", El Noroeste, 11 de noviembre de 1933).

6 Editorial sin título, El Noroeste, 23 de octubre de 1931. 
que atribuyen a la palabra democracia. Ésta no debe identificarse sencillamente con el gobierno por el pueblo y para el pueblo. Para los liberaldemócratas, sería más correcto considerarla el gobierno de los ciudadanos para los ciudadanos. La diferencia no es tan nimia como pueda parecer. En primer lugar, no puede identificarse jamás al pueblo con una clase social determinada. Los partidos clasistas no son en realidad democráticos - una vez más, el antisocialismo de los postulados melquiadistas se hace patente- pues no ejercen el poder en beneficio de la sociedad en su conjunto, sino en una parte de ella. Para el auténtico demócrata, pueblo no quiere decir proletariado, ...sino todas las clases que lo integran: nobleza, burguesia, clase media, intelectuales y trabajadores ${ }^{7}$. El interclasismo, pues, forma parte de la definición ideológica del partido, pero un somero análisis de su propaganda nos llevaría a conclusiones bien distintas que no es éste el lugar para detallar. Baste ahora con decir que en la práctica es la clase media la destinataria natural de unas ideas que, como iremos viendo a lo largo de este trabajo, ni se plantean la alteración de las relaciones sociales ni confían en absoluto en la clase obrera como artífice de su propia redención.

En segundo lugar, democracia es algo bien distinto de la demagogia. Ésta no es sino el gobierno de las masas callejeras, que es el disfraz más sutil que puede adoptar el despotismo, pues detrás de ellas está siempre el que las manipula; aquélla, el gobierno del pueblo elevado a la categoría de ciudadano consciente por obra de la cultura. Un gobierno, además, ejercido a través de los cauces legales previstos: el sufragio universal, la discusión parlamentaria e incluso el ejercicio directo de la soberanía popular por medio del referéndum. Los límites entre libertad y anarquía se encuentran precisamente aqui, en la legalidad. Abiertos en la República los cauces de la legalidad, sólo legalmente y en su tiempo debe manifestarse el pueblo. No hay régimen que pueda vivir en el descontento y en la desobediencia constante. Constituido el gobiemo, hay que respetarlo ${ }^{8}$ Una concepción de la democracia, en suma, evidentemente jurídica, pero que no consigue ocultar por completo un temor visceral a las masas populares y bajo la cual subyace el elitismo propio de los mesócratas. Estos, acostumbrados a percibirse a sí mismos como clase dirigente natural, no conciben otra receta para el progreso del país que dirigir ellos mismos la regeneración del pueblo por medio de reformas desde arriba concebidas y puestas en práctica sin participación

CUBER, M.: Melquiades Álvarez..., pág. 139.

Cuber, M.: "Sobre el acto del Palace. Melquiades Alvarez. Criterio (ill)". El Noroeste, 7 de junio de 1931. 
de aquél y encaminadas a su redención por obra del progreso cultural y económico. Encontramos aquí la culminación de la influencia krausista que más arriba apuntábamos y que quizá cabría esperar al menos debilitada por la deserción de los intelectuales que el reformismo se vio obligado a afrontar como resultado del evidente fracaso de su táctica accidentalista durante los estertores de la monarquia alfonsina. Como vemos, los intelectuales han abandonado el partido, pero sus ideas persisten.

Naturalmente, lo hasta aquí expuesto conduce a preguntarse qué puesto conceden los melquiadistas respectivamente al orden y a la libertad en su jerarquía de valores políticos. La cuestión no carece de importancia. Como señalaba un editorial de Crisol en mayo de 1931, De la delimitación que haga el gobernante dependerá el que la política desarrollada sea liberal o conservadora ${ }^{9}$. La que hacía el Partido Republicano Liberal Demócrata era, parece claro, más conservadora que “liberal». Es cierto que el partido rechaza con contundencia el fascismo precisamente por su carácter antiliberal, pero también lo es que las clases medias europeas, educadas en el liberalismo, prefirieron abrazar a aquél como mal menor capaz de proteger sus intereses frente a la amenaza comunista, real o supuesta. De forma similar parece razonar Mariano Cuber cuando, tras recordarnos que el fascismo, por su carácter estadolátrico, es tan inadmisible para un liberal como el comunismo, con el cual presenta ...más que antítesis, afinidades..., afirma sin rubor que puestos a elegir entre ...dos males inevitables...es ....más tolerable para cualquier país una dictadura inteligente que una proletaria ${ }^{10}$. Y no debe pensarse que esta es la posición del partido al final de la República, cuando ya ha experimentado un fuerte proceso de derechización, asustado, como una buena parte de las clases medias, por el «desorden", en parte real y en parte magnificado interesadamente desde los sectores políticos más conservadores. No, la insistencia en la vinculación indisoluble que debe existir entre orden y libertad es característica del partido desde los mismos comienzos de la República. En su famoso discurso del Palace, en mayo de 1931, ya habia pronunciado Álvarez palabras como éstas: Por eso nosotros, al prevenirnos contra la licencia y al trabajar por el orden y por la libertad, realizamos conjuntamente una labor republicana y una labor patriótica. Y más adelante: La República, por su naturaleza es inseparable de la justicia y de la libertad, y ambas reclaman indispensablemente el mantenimiento del orden ${ }^{11} . Y$ en septiembre de

\footnotetext{
Crisol, 26 de mayo de 1931.

Cuber, M.: Melquiades Alvarez..., pág. 173.

1 "La candidatura de Apoyo a la República por Madrid", Ahora, 25 de junio de 1931
} 
1931 proclama en las Cortes que...el poder del pueblo, en ciertas condiciones y momento, puede ser tan peligroso como el poder absoluto de los reyes ${ }^{12}$. La obsesión, no obstante, se acentuará durante los meses siguientes, mientras los partidos de izquierda administran el régimen. En el discurso clave del Teatro de la Comedia, en el que Álvarez ofrece su apoyo a Lerroux, pronuncia el caudillo liberal demócrata otras frases no menos elocuentes:

Por esto aceptamos dos postulados: respeto ciego a la ley y robustecimiento de la autoridad para que los mandatos de la ley se hagan efectivos. El orden es el oxigeno de la República y cuando el orden se quebranta entre las agitaciones del tumulto, el pueblo pierde su cetro soberano y se convierte en esclavo de la demagogia ${ }^{13}$.

En tercer y último lugar, el concepto de la democracia de los liberales demócratas se vincula también de modo indisoluble al liberalismo en lo que se refiere a la cuestión de los derechos individuales. Estos no son algo que se concede a los ciudadanos por obra de una mayoría que los vota graciosamente, y que de la misma manera podría privarles de ellos. No son fruto de un ordenamiento jurídico, por lo que no pueden ser cambiados por un ordenamiento jurídico. Los derechos del ciudadano son inalienables, los posee como un rasgo inherente a la naturaleza humana, y en consecuencia la democracia ha de ser entendida como gobierno de la mayoria, pero limitado por la obligación de respetar los derechos de la minoría. Por esa razón, en la República, régimen democrático, han de tener cabida también aquellos que no se proclaman republicanos, aunque esto no sólo por principio, sino por mero instinto de supervivencia. No cabe exigir certificados de pureza de sangre republicana, pues con ello se cava la propia tumba del régimen. Expulsando de la política a los que no se sienten republicanos se les invita a perseguir sus fines por medios no políticos, es decir, violentos, lo que pone en peligro la estabilidad de la República que se dice querer defender. Álvarez, volviendo una vez más los ojos hacia Francia, pone como ejemplo de esa actitud a Gambetta, quien ... decía que era indispensable atraer a la República a los legitimistas y a los bonapartistas, única manera de que aquélla institución engendrada en el desastre trágico del Sedán, no se viera sorprendida con un golpe de mano que comprometiera su existencia... ${ }^{14}$.

12 Crisol, 9 de septiembre de 1931.

13 Texto taquigráfico del discurso en El Noroeste, 5 de enero de 1932.

14 Discurso de Álvarez en los Campos Eliseos de Gijón, El Noroeste, 29 de agosto de 1933. 
Naturalmente, estos postulados democrático-liberales han de conducir a la defensa de un modelo determinado de Estado, capaz de aplicar tales principios en la práctica con ciertas garantías de permanencia. La primera cuestión que se plantea, en un orden lógico, es el tipo de régimen que se prefiere y las razones que se dan para ello. En el caso del melquiadismo, como es sabido, había sido rasgo característico principal la defensa de la accidentalidad de las formas de gobierno, es decir, de la idea según la cual éstas son una cuestión secundaria frente a lo verdaderamente esencial: la existencia o no de democracia. Desde este punto de vista, una monarquía puede ser tan válida como una república siempre que cumpla los requisitos exigibles a un régimen democrático y, al contrario, una república no es admisible si deviene instrumento de una oligarquía. Esta foma de contemplar el problema del régimen, que había encontrado su funcionalidad bajo la Monarquía al eliminar el principal obstáculo que, desde su propio punto de vista, separaba al reformismo del gobierno - sus origenes y su filosofía republicanos- no será abandonada cuando se proclame la República. El partido seguirá proclamándose accidentalista, sólo que ahora, al contrario de lo que había hecho antes, y por razones obvias, hará más hincapié ante la opinión en aquellos aspectos más específicamente republicanos de su pasada ejecutoria política. Desde su prensa se recordará reiteradamente su colaboración sincera en la revolución de 1917, así como su participación en la Conjunción Republicano- Socialista, y se recordará que, a pesar de su accidentalismo, el melquiadismo nunca dejó de considerar a la República una forma de gobierno más perfecta que la Monarquía, a la que, además, siempre se pretendió aproximar a aquélla. Como recuerda Pedregal en el Banquete del Palace, se trataba de ...utilizando las escasísimas posibilidades que la política española ofrecia, intentar la transformación de sus instituciones, convirtiéndolas en una república (...) jamás entendió el partido reformista que el objetivo era la evoluci de las personas hacia la monarquia, sino la de las instituciones hacia la república (...) hasta convertir las instituciones monárquicas, que entonces eran bien levemente combatidas, en una democracia tal, que sólo un levísimo accidente la separara de la República, y ese accidente había de franquearse en cuanto la conciencia pública quisiera salvarlo... ${ }^{15}$. Por otra parte, la táctica reformista había tenido su razón de ser en el contexto de un republicanismo maltrecho y desorientado, paralizado por las querellas intestinas inducidas por los más nimios matices doctrinales y los orgullos

15 Intervención de J.M. Pedregal en el Banquete del Hotel Palace de Madrid, El Noroeste, 26 de mayo de 191. 
personales más inconfesables. ¿Era ese republicanismo una alternativa a la monarquía?...Mantenido el republicanismo en la fórmula histórica, divorciada de los problemas sociales, y prometiendo la Corona adoptarlos, previa una modificación de su conducta, el reformismo fue la ilusión de unos republicanos que creyeron posible la libertad y la democracia españolas a la manera inglesa ${ }^{16}$.

Por otro lado, el PRLD no necesitaba reinventar una tradición republicana a la que ya pertenecía. Si acaso se le podía repochar haber cometido un error táctico, haber caído en la ingenuidad de creer que la monarquía podía democratizarse sin traumas, pero no haber roto los lazos espirituales con el republicanismo, dentro de cuyo mundo simbólico seguía moviéndose con naturalidad. Lo prueban así aspectos que podríamos denominar folclóricos, como la decoración de las salas donde se celebraban los mítines con banderas tricolores ${ }^{17}$, el uso de la Marsellesa como música de fondo en los actos del partido ${ }^{18}$, o la celebración como si de una fiesta religiosa se tratara del aniversario de la Primera República, el 11 de febrero de cada año ${ }^{19}$. Se trataba, como ha estudiado José Álvarez Junco ${ }^{20}$, de signos de la participación en un universo mental poblado de símbolos compartidos cuya posesión difícilmente se podía simular. Pero no acaban ahí las similitudes. Si, como ha estudiado, por ejemplo, Ángeles Egido ${ }^{21}$, era rasgo característico de la mentalidad republicana española la admiración por lo francés, no cabe duda de que los liberal-demócratas compartían esta admiración. La Revolución Francesa aparece a menudo en sus discursos no sólo como progenitora ideológica, sino también como fuente de ejemplos a imitar, y cuando se trata de argumentar en favor de una opción concreta ante un problema, como si de un argumento de autoridad se tratara. Asi ocurre cuando se apela como modelo al unitarismo

16 SuArez Solís, R.: "Actualidad española. Don Melquiades Álvarez", Diario de la Marina, La Habana, Cubana, sin techa. Reproducido en El Noroeste del 13 de mayo de 1931. Véase también un discurso del abogado gijonés, militante del PRLD, Dionisio Morán Cifuentes, en El Noroeste, 8 de septiembre de 1931.

7 "Por el Oriente de Asturias. Una excursión de Melquiades Álvarez", El Noroeste, 2 de septiembre de 1932

is Asi se recibe, por ejemplo, a Álvarez en un acto celebrado en Gijón, El Noroeste, 16 de julio de 1932.

is "Conmemoración del 11 de febrero. Partido Republicano Liberal Demócrata. Nota oficiosa", El Noroeste, 10 de tebrero de 1933.

20 Álvarez Junco, J.: "Los amantes de la libertad. La cultura republicana española a comienzos de siglo xx». En Townson, N. (ed.): El republicanismo en España (1830-1977). Madrid Alianza Editorial, 1994.

" EGIDO LEON, A.: "La imagen de Francia en la España republicana", Cuadernos Republicanos, $n^{\circ}$ 19, Madrid, julio de 1994. 
francés frente a la supuesta disgregación del Estado que a decir del partido supondrá el Estatuto catalán ${ }^{22}$, o cuando se defiende una solución evolutiva y tolerante para la cuestión religiosa, contraria al radicalismo de que hace gala el gobierno en opinión de los lideres liberal-demócratas ${ }^{23}$.

Pero si podía admitirse que un régimen fuera monárquico con tal de que fuera democrático, había rasgos que resultaban poco deseables en una República. Si la extralimitación del Gobiemo en el uso del poder era uno de ellos, como hemos visto, también lo era la posibilidad de que el Parlamento aprobara leyes extremas sin que existiera ninguna fuerza de contrapeso que limitara esa posibilidad. Por ello, si el PRLD se proclama defensor del parlamentarismo, no lo será de los parlamentos convencionales (es decir, del tipo convención, que asume todos los poderes), sino de la estricta separación de poderes y del bicameralismo, en el que verá una garantía de moderación y de estabilidad y una defensa contra la posible tiranía de las mayorias. No es raro, pues, que el melquiadismo rechazara una Constitución con la que difícilmente podía identificarse.

$Y$ es que la preocupación por la moderación será uno de los rasgos más caracteristicos del PRLD. El partido se había definido a sí mismo como "reformista", y decir reformismo equivale a decir evolucionismo. Tal como lo interpretaban sus líderes, ser evolucionista o reformista significaba rechazar toda solución radical a los problemas del país, al que se pretendía sacar de su atraso por medio de la aplicación lenta y progresiva de reformas eficaces, pero a la vez equilibradas y respetuosas siempre con los principios de la democracia liberal, pues la introducción de medidas demasiado avanzadas no podía sino generar en la sociedad una respuesta de rechazo capaz incluso de producir una involución. Como señala Alvarez, la verdadera receta del progreso... no consiste en caminar a saltos y precipitadamente, sino que consiste en caminar con firmeza, pero sin retroceder jamás, llevando a la realidad aquellas ideas que han fecundado en el espiritu público, pero llevando siempre al espíritu público aquellas otras que necesitan precisamente de su calor fecundante para fructificar y para madurarse. $Y$ no es prudente, por el contrario, poner en marcha... reformas precipitadas que no están en la conciencia pública... pues no tendrán otro efecto que suscitar...la hostilidad y la enemiga contra el régimen republicano ${ }^{24}$. Se trataba, en última instancia, de no asustar a esos grupos sociales que alguno de los diarios próximos al

\footnotetext{
"Lerroux y el Estatuto de Cataluña", El Noroeste, 22 de mayo de 1932.

"La República no persıgue ninguna religion". El Noroeste, 10 de julio de 1932.

24 Discurso de Álvarez en el Palace, El Noroeste, 26 de mayo de 1931.
} 
centrismo republicano denomina clases productoras, es decir, los empresarios y, por extensión, las clases pudientes del país. Pero también era un objetivo fundamental de esas reformas apartar de la tentación revolucionaria al proletariado consciente y organizado. El evolucionismo, por tanto, no es sólo el mejor instrumento del progreso; es también la mejor arma contra la revolución:

...no hay otra salida ni otro remedio a la realidad que vivimos que andar hacia adelante constantemente, despacio si se quiere y es posible; pero andar siempre, so pena de exponemos, si no lo hacemos, a que un dia las fuerzas ocultas que mueven el mundo nos hagan dar uno de esos saltos tremendos que registra la Historia como cataclismos ${ }^{25}$.

Hay otro aspecto que resulta de obligado análisis al aproximarse a la ideología de un partido en la España de los años treinta: su posición ante el fenómeno religioso. Como heredero que es de la tradición republicana, en la que Alvarez, no lo olvidemos, había crecido cultural y políticamente, el melquiadismo no puede dejar de ser laico. Puede objetarse, con razón, que el laicismo es una opción dentro de la que caben distintos enfoques y diversos grados, y en efecto no es igual el laicismo que defienden los liberal-demócratas que aquél con el que se identifican los republicanos de izquierda, sobre todo los radical-socialistas, en cuyas filas militaban algunos de los más destacados jabalíes del primer bienio. Los límites del laicismo liberal-demócrata quedan bien trazados en una frase que con frecuencia repiten los dirigentes del partido: Defendemos el laicismo del Estado, no de la sociedad. En otras palabras: la religión, como fenómeno espiritual y moral que siempre ha estado presente en la vida colectiva de los pueblos, merece todo el respeto; su ingerencia en el ámbito de lo estatal, por el contrario, no debe ser permitida, pues de ella no pueden sino derivarse perniciosas consecuencias. La religión ha sido un factor que ha contribuido y contribuye a la civilización, facilitando la evolución de los hombres hacia la ciudadanía y refrenando sus tendencias instintivas. Es, además, algo que se relaciona con el ámbito de lo íntimo, de la conciencia y el sentimiento, frente a lo que un liberal no puede sino manifestar respeto y tolerancia, consagrándolo así en los textos legales. Pero del fenómeno religioso a través de los tiempos ha ido contaminándolo con intereses materiales que a menudo se confunden interesadamente con él dando así lugar a maniobras orientadas a la preservación de esos intereses bajo el pretexto de la defensa de la religión en sí. Tales

25. Editorial sin título, El Noroeste, 18 de octubre de 1931. 
maniobras suelen adoptar la forma de ingerencias en aquellos aspectos de la vida colectiva que no corresponden al ámbito de la fe, sino al de la política, cuyo único administrador légitimo es el Estado. El lógico corolario de estos argumentos es la necesidad de la separación entre la Iglesia y el Estado, garantizándose a la primera libertad completa para el desarrollo de las funciones que le son propias, y de otras no específicas a las que todo ciudadano tiene, como tal, derecho. Por ello, la Iglesia podrá, además de celebrar todos los actos propios del culto, producir, comerciar e incluso enseñar si así lo desea, pero sometiéndose en todo ello a la supervisión estatal.

No obstante, el evolucionismo que considerábamos principal característica de los liberal-demócratas va a manifestarse tambien aquí. La separación que se postula como necesaria no se defiende como inmediata, sino como algo que se producirá en el futuro, tras un dilatado período de preparación de la opinión. En este caso, esa preparación no viene exigida tanto por la posible reacción violenta de las conciencias católicas opuestas a la medida, sino porque la Iglesia, libre de repente de la vigilancia del Estado, y al actuar sobre individuos aún no acostumbrados a la convivencia democrática, podría usar su gran poder de movilización ideológica contra la misma democracia y contra el Estado. Conviene, pues, establecer un prolongado período en el que el Estado ejerza una vigilancia constante sobre la Iglesia, que ya no sería, así, una organización más con absoluta libertad de actuación dentro de la ley, sino un ente peligroso por su capacidad de manipulación de las mentes populares, en su mayoría y moldeables, al que hay que mantener en cuarentena. El laicismo liberal-demócrata deviene asi, inopinadamente, en regalismo.

Hay que decir, no obstante, que dentro del partido conviven distintas sensibilidades. Las bases tradicionales, sobre todo las asturianas, son más anticlericales. Si la cupula rechaza la legislación anticlerical del primer bienio por considerarla atentatoria contra los derechos de los ciudadanos, sobre todo lo referente a la privación a las órdenes de la libertad de enseñar, producir y comerciar, tenemos constancia de que los simpatizantes del partido no veían con desagrado tales medidas. Así, por ejemplo, El Noroeste, portavoz oficioso del melquiadismo en Asturias, no da mucha importancia al tema:

¿Pero es que podia presumirse que la cuestión religiosa tuviese, con una Repuiblica laica, otra solución peor ni mejor que la que ha tenido? (...) No es (...) la cuestión religiosa, sino la económica, la que conmueve hoy profundamente la vida de la República. Por motivos religiosos nadie en estos tiempos 
se echa un fusil al hombro (...) En cambio, por motivos económicos andamos a tiros un día si y otro también ${ }^{26}$.

Los mismos lectores manifestaban con frecuencia su acuerdo con lo esencial de las medidas tomadas por el gobierno e incluso protestaban por lo incompleto de su aplicación ${ }^{27}$. E incluso los estratos dirigentes intermedios, los que ocupaban puestos de responsabilidad en ayuntamientos o corporaciones provinciales, sintonizaban más que los dirigentes nacionales con el anticlericalismo del primer bienio. Prueba de ello es, por citar un caso representativo, el hecho de que los concejales liberal-demócratas de Oviedo prestaran su voto a una moción que felicitaba al Gobierno por la expulsión de los jesuitas, a la que, como sabemos, Melquiades Alvarez no se había mostrado favorable ${ }^{28}$. Los nuevos militantes, por el contrario, atraídos por la creciente moderación de que hacía gala Alvarez y por su imparable enfrentamiento con los gobiernos del primer bienio, serán, por su parte, bastante menos radicales, postura que coincide cada vez más con la de un partido que realiza a lo largo de la República un considerable viraje hacia la derecha, mucho más manifiesto en la táctica que en la ideología, que no parece sufrir modificaciones.

Este giro a la derecha del melquiadismo no era nada nuevo. En el fondo, el reformismo se había caracterizado bajo la Monarquía por un progresivo retroceso hacia posiciones de exigencia decreciente con la renovación del régimen, al que le había ido pidiendo cada vez menos para entrar en el gobierno. Tanto es así, que el Partido reformista acabó dando todo a la Monarquia sin obtener de ella ni siquiera una promesa concreta de democratización efectiva. Como indica Suárez Cortina ${ }^{29}$, quizá se

26 Editorial sin título, El Noroeste, 18 de octubre de 1931.

27 En El Noroeste, en la sección de información regional, a menudo se incluyen cartas de lectores del diario en los pueblos asturianos que protestan porque no se ha realizado la secularización del cementerio local (Ablaña, 10 de febrero de 1932; Navia, 2 y 11 de febrero de 1932). El 12 de marzo de 1932, una noticia de la misma sección titulada "La Felguera. De enseñanza" dice lo siguiente: ...una maestra de este pueblo se obstina en continuar haciendo propaganda religosa en la escuela. Esto está rigurosamente prohibido por la Constitución, y si dicha maestra no respeta las leyes, llamaremos la atención de quien corresponda. No hay que olvidar tampoco las frecuentes puyas lanzadas desde los editoriales del periodico contra la derecha confesional, a la que suele aludirse bajo el apelativo de cavernocracia, expresión que pretende reflejar una fuerte connotación retardataria frente a la que, implicitamente, EI Noroeste y el PRLD se sitúan del lado del progreso y la modernización. Como es obvio, desde noviembre, de 1933, fecha de la alianza electoral en Asturias del melquiadismo con la CEDA, tales alusiones desaparecen.

28 El Noroeste, 3 de febrero de 1932.

29 SuArez Cortina, M.: "Melquiades Álvarez, liberal y demócrata", Bulletin d'Histoire Contemporame de l'Espagne, $\mathrm{n}^{\circ}$ 10, diciembre de 1989, págs. 24-34. 
tratara del efecto de la lógica evolución de las clases medias y pequeñoburguesas que formaban lo esencial de las bases del melquiadismo. Estas clases, progresistas en una primera etapa de crecimiento, se vuelven conservadoras cuando su posición económica, ya consolidada, les coloca en situación de perder más que ganar con cambios que podrian favorecer a la mayoría de los componentes de una sociedad en la que ellas figuran ya entre las minorias privilegiadas.

\section{EL PROGRAMA}

Damos con esto por terminado el análisis de la ideología del Partido Republicano Liberal Demócrata. Es hora ya de que pasemos a ver cómo se plasmaba aquélla en el terreno de los problemas concretos 0 , en otras palabras, en la materialidad de un programa político. Las Asambleas Nacionales del partido, celebradas con alguna regularidad bajo la República, trataron, desde luego, aspectos programáticos, pero la prensa no recoge sino fragmentos y nunca un programa oficial completo. De existir éste, por tanto, se perdió con el resto de los papeles del partido. De cualquier modo, si existió un documento-programa, no parece que contase con gran difusión. El mismo Cuber, uno de los militantes del partido más preocupados por los temas ideológicos y programáticos y con mucho la fuente principal de la que disponemos, lo da a entender en su obra de 1935 sobre Melquiades Álvarez al afimar que Puede haber alguna diferencia de apreciación al darle forma articulada [al programa] y alguna de matiz al desenvolverio ${ }^{30}$. Desde luego, si hubiera circulado una versión oficial del programa del PRLD entre sus dirigentes al menos, no habria tenido sentido que Cuber crease por sí mismo una versión articulada como la que nos ofrece en su obra, con el riesgo evidente de discrepar de aquélla. La misma impresión transmite, por otro lado, un comentario pronunciado en el transcurso de la Asamblea Nacional del PRLD celebrada en mayo de 1934 por Lorenzo Ortiz Cañavate, a la sazón presidente de la sección segunda de la Asarnblea, precisamente la dedicada a las cuestiones de ideario y programa. Según el periodista que resume la noticia, el citado presidente había dado cuenta de las ...dificultades con que se tropiezan para recopilar la doctrina reformista a través de tantos discursos, de verdadera exponente nacional durante los últimos años, discursos que fueron como una obra legislativa que siempre redundó en beneficio de España. Y más

30 Cuber, M: Melquiades Alvarez..., pág. 113, nota al pie. 
adelante, en una frase aún más elocuente, llega a decir el responsable del programa del partido que la obra de Melquiades Alvarez es comparable nada menos que con...la Constitución inglesa, que aunque escrita, está sin resumir ni ordenada ${ }^{31}$. Nuestras fuentes, por tanto, serán, en lo esencial, la obra de Cuber, matizada por los artículos y editoriales publicados en la prensa afin al partido. En un afán de sistematización, intentaremos aproximarnos a lo que seria el programa del PRLD centrándonos en aquellas cuestiones fundamentales que, a nuestro entender, tenia planteadas España en los años treinta de nuestro siglo. Estas cuestiones serian la agraria, la social, la regional, la religiosa y la de la enseñanza. Para ofrecer una versión más completa de los puntos de vista del partido, nos referiremos también, aunque con menor atención, a otros aspectos de importancia secundaria en la coyuntura del momento histórico en el que nos encontramos.

La cuestión agraria es de las que más preocupan al partido. Esto es asi por necesidad, ya que aunque el PRLD es un partido político de vocación mesocrática, buena parte de sus votos en las dos regiones en las que se asienta con mayor fuerza, Asturias y Salamanca, se los debe a las gentes del campo. Esto explica la gran atención que dedica su prensa a los problemas agrarios, que nos permite llegar a una definición bastante precisa de la postura liberal-demócrata acerca del tema.

Como hemos visto más arriba, los antiguos reformistas parten en sus tesis sobre el problema agrario de una concepción muy definida de la propiedad de la tierra. Si en general la propiedad es un derecho sagrado e inviolable, la referida a la tierra es una excepción, por cuanto no es, como la del capital, fruto del ahorro y, por tanto, hija en última instancia del trabajo, sino que es eterna; está ahí desde siempre.

..el dominio de la tierra, por recaer sobre la única cosa que no procede del trabajo, nunca puede merecer la consideración de derecho absoluto, sino de una mera investidura concedida en atención a la utilidad general. La propiedad separada del trabajo no es un derecho. Es un hecho... ${ }^{32}$.

Y precisamente por ser un hecho, debe quedar condicionada al cumplimiento de una función social, de una utilidad general que, de no ser respetada, faculta al Estado a intervenir en nombre de ese principio por medio de

\footnotetext{
31 "La Asamblea del Partido Republicano Liberal demócrata", El Noroeste, 27 de mayo de 1934.

32 Senador Gomez, J.: "La República y la Tierra, El Noroeste, 2 de julio de 1932.
} 
la expropiación compensada. ¿Cuándo incumple el propietario su función social?. Cuando explota inadecuadamente la tierra, extrayendo rendimientos inferiores a los posibles; cuando la dedica a funciones distintas de la producción, como el recreo; cuando la convierte sistemática y continuadamente en fuente de rentas por medio de terceros, aunque en este último caso se prefiere, antes que la expropiación, el gravamen de la tierra con impuestos superiores para animar al propietario al cultivo directo.

Con las fincas asi obtenidas, el Estado creará patrimonios familiares inalienables que serán vendidos a las familias de campesinos sin tierra. El rechazo a la creación de una clase de arrendatarios de tierras estatales y a la posibilidad de explotación colectiva de las tierras fruto de expropiación es total. Como partido burgués que es, el PRLD desea, en última instancia, que la Reforma Agraria dé lugar a la aparición de una sólida clase media rural de instintos conservadores y que actúe como firme sostén del régimen republicano liberal.

No debemos creer, no obstante, que el acuerdo es unánime dentro del partido. A veces parece, incluso, que tales afirmaciones sobre la reforma son más una fachada que un deseo real de ponerla en práctica, al menos alli donde el melquiadismo tiene realmente fuerza en el campo. Nunca se niega explícitamente su necesidad, pero desde la prensa afín se presenta como algo que debe limitarse a las regiones latifundistas como Andalucía y Extremadura. Como en éstas no tiene mucha fuerza el partido, y como alli donde sí la tiene, como en Asturias, se rechaza cualquier posible reforma agraria basada en la expropiación, no deja de sonar todo esto a postura de cara a la galería. El hecho de que el sector del partido que de verdad defiende una reforma agraria, el dirigido por Villalobos, acabe separándose del mismo, al ver, entre otras cosas, qué "reforma» era la que ponían en práctica los gobiernos de la CEDA, con apoyo de Melquiades Alvarez, podría ser una prueba de la falta de sinceridad del PRLD en este asunto. Lo cierto es que en Asturias, el mayor baluarte del melquiadismo, las soluciones propuestas son muy tradicionales. Se dice que la República en sí ya ha logrado la emancipación del campesinado astur al liberarle de las redes caciquiles. Basta, por tanto, con responder al que siempre ha sido su anhelo: la extensión de la propiedad. Pero como en Asturias no hay latifundios de donde esa propiedad pueda obtenerse, no queda sino perfeccionar los arrendamientos hasta convertirlos en algo similar en la práctica al patrimonio familiar indivisible que se postula como panacea universal para los problemas del campo. En última instancia, los avances técnicos para aumentar la productividad; la creación de escuelas rurales para difundirlos; la introducción de cooperativas de crédito, compra y venta; la prolongación de los contratos de arrendamiento, y la introducción en sus 
cláusulas de condiciones ventajosas para el arrendatario como la imposibilidad del desahucio si no es por falta de pago, el reconocimiento de las mejoras efectuadas y la protección contra los desastres naturales serán las recetas a las que se limitará el programa real del PRLD para el campo. De este modo, dirá uno de sus teóricos sobre el tema, Julio Senador, ...la propiedad se comparte entre arrendadores y arrendatarios... ${ }^{33}$. Asi las cosas, el interclasismo del PRLD se nos aparece demasiado limitado por el deseo escrupuloso de no atentar contra los intereses de las clases dominantes.

Para completar esta impresión debemos analizar las posiciones del partido ante la llamada cuestión social. Dentro de la cosmovisión liberal que caracteriza al melquiadismo, el Estado, que, como vimos, debía quedar reducido a la mínima expresión, posee, no obstante, atribuciones que le permiten intervenir en las relaciones sociales. Atribuciones que, todo hay que decirlo, no son sino simple derivación de la función de administrar justicia, inherente a la esencia estatal misma. Basta con añadirle el calificativo social a la justicia para que el Estado quede legitimado para intervenir en las relaciones entre capital y trabajo sin pecar por ello de socialismo.

$Y$ es que, en efecto, poco tiene de socialista el programa liberal-demócrata en este ámbito, aunque Alvarez se proclame socialista en alguna ocasión ${ }^{34}$. Sus propuestas, timoratas incluso para un partido de centro, se quedan en el marco de lo puramente arbitral, de la mera intermediación estatal entre obreros y patronos, eso sí con amplias competencias para los tribunales -ordinarios - a los que se encargaría incluso la misión de fijar salarios y demás condiciones de trabajo, que se verían alteradas sólo de cambiar significativamente la coyuntura del mercado. Un rasgo de claro intervencionismo, pero en un sentido por completo conservador, revela, sin embargo, la intención, manifestada por Cuber ${ }^{35}$ en un momento ya de máxima derechización del partido, de elimiriar el derecho de huelga a cambio del establecimiento de un tope para los beneficios empresariales por encima del cual sería obligatoria la participación en ellos de los obreros. No creemos, sin embargo que tal opinión pueda considerarse representativa del programa del partido aunque Cuber así lo afirme, porque su alejamiento de los dogmas liberales que lo caracterizan es enorme y desentona de las soluciones propuestas en los otros campos.

33 Senador Gomez, J.: "La República...".

34 Véase el discurso pronunciado por Álvarez en el Teatro Campoamor de Oviedo en El Noroeste, 26 de julio de 1932.

35 CuBER, M.: Melquiades Alvarez..., págs. 231-235. 
Así, por ejemplo, respecto a las organizaciones sindicales, la actitud del PRLD es la típica del liberalismo moderno: respeto y legalidad absolutas, pues la represión de aquellas organizaciones en apariencia más peligrosas para el orden social no haría sino acrecentar su cohesión y fuerza, volviéndolas aún más temibles. La medicina más eficaz no es otra que la libertad: ...quiero que esos elementos sindicalistas que tanto pavor infunden a ciertas clases sociales, se disciplinen entrando, al amparo de la libertad, en los cauces del derecho... Ahora bien ...la libertad que yo les conceda, que les va a conceder este partido, que se va a consagrar, seguramente, en la Constitución, es una libertad que lleva aparejada indiscutiblemente la responsabilidad; es una libertad que exige la intervención del poder... Y asi, de ese modo, lenta y evolutivamente, como le gusta al partido, ...esas fuerzas revolucionarias (...) se irán convirtiendo, por el progreso social, en fuerzas del carácter conservador, que cooperarán en la obra de la libertad $y$ al afianzamiento de las instituciones ${ }^{36}$. Porque, en el fondo, tal es la misión que los liberal-demócratas reservan a las organizaciones sindicales: ...organizar a las masas obreras en sindicatos de defensa, y (...) hacer conciencia de ciudadanía en los trabajadores, educándolos como elementos propulsores de la evolución que viene elaborando las bases de la sociedad del futuro. Todo lo que sea salirse de este marco de ideas y de acción es caer en la perturbación sistemática que hunde a los pueblos en la catástrofe, en la miseria y en el dolor ${ }^{37}$. Esa es la preocupación que verdaderamente subyace tras las protestas de justicia social del PRLD: la del conservador inteligente que asume las reformas como valladar contra la revolución y que considera preferible ceder en parte a las reivindicaciones del proletariado organizado que arriesgarse a un incremento de la tensión social que haría más fácil un estadillo revolucionario ${ }^{38}$.

Pero lejos de la alteración de las relaciones sociales vigentes, e incluso de las reformas verdaderamente capaces de mejorar la situación de los trabajadores, las soluciones propuestas por el partido son de tono típicamente armonicista, al estilo democristiano. El objetivo último de toda política económica ha de ser, desde su punto de vista, el incremento

36 Discurso de Álvarez en el Palace, El Noroeste, 26 de mayo de 1931. Véase también otro discurso en Gijón en El Noroeste, 8 de septiembre de 1931.

37 Editorial sin título, El Noroeste, 13 de septiembre de 1933.

38 Buen ejemplo de ello es la actitud que manifiesta la prensa del partido ante el problema minero asturiano. Pueden verse al respecto los sigueintes editoriales de El Noroeste: "Situación económica y social de los mineros asturianos" (3 de julio de 1931), "Comprensión, tolerancia y transigencia" (11 de julio de 1931), "Un peligro para la República. El Gobierno Provisional y la Confederación Nacional del Trabajo" (12 de julio de 1931), editorial sin titulo del 23 de julio de 1931 y "Las clases trabajadoras y el nuevo régimen" (28 de julio de 1931). 
global de la riqueza, pues sin riqueza que repartir no puede resolverse el problema de la pobreza. Este incremento de la riqueza no puede alcanzarse, sin embargo, por medio del enfrentamiento entre el capital y trabajo, sino sólo a través de la colaboración entre ambos. Destruir el primero con la intención de obtener supuestos beneficios para el segundo no puede ser más que contraproducente. No es extraño, pues, que los liberaldemócratas aplaudieran el discurso de Ortega en las Cortes en julio de 1931, en el que el filósofo había sostenido la creciente aproximación entre capitalismo y socialismo.

Otra cosa es cómo se articulan estos principios en medidas concretas. Aquí se manifesta la contradicción más evidente entre unos postulados colaboracionistas y una praxis que apuesta por el capital más que por el trabajo. No sólo se desentiende el partido de la captación de apoyos entre el proletariado, del que suele acordarse tan sólo para pedirle paciencia y recomendarle que no se deje arrastrar por los cantos de sirena revolucionarios, sino que reacciona negativamente ante cualquier sugerencia desde la izquierda respecto a la cogestión obrera de las fábricas $u$ otras medidas similares de colaboración. La impresión que deja esta actitud no puede ser otra que la de una grave incongruencia entre una doctrina supuestamente armonicista y una práctica volcada hacia los intereses de las clases medias y pudientes.

En cuanto a la llamada cuestión regional, no deja de ocurrir algo similar. En teoría el partido se muestra favorable a la concesión de amplias autonomías regionales en todo aquello que sea compatible con el principio superior de la unidad de la Nación española, única que se reconoce, y siempre dentro de una articulación unitaria, no federal, del Estado. En apariencia, por tanto, el PRLD se muestra sensible y abierto hacia una solución relativamente avanzada del problema planteado por la existencia de nacionalismos periféricos que demandan el necesario desenvolvimiento de su personalidad peculiar. Un análisis más detenido ha de llevarnos forzosamente a conclusiones bien distintas.

Álvarez repite a menudo que está a favor de la unidad, pero no de la uniformidad. La primera es un hecho innegable, que se ha forjado como resultado de la naturaleza y de la Historia, y es acorde con la marcha del progreso humano, que camina desde la disgregación a la unificación. La segunda, por el contrario, es fruto de una política consciente desarrollada por los monarcas de las Casas de Austria y de Borbón, ... una cosa artificiosa, falsa, mezquina.. ${ }^{39}$, impuesta por encima de las peculiaridades innegables 
de las regiones españolas. La receta que corresponde aplicar a la República, en consecuencia, no será otra que, salvando la unidad, eliminar la uniformidad, lo que colocará a las regiones en situación de colaborar a la mayor grandeza de la Nación a la que todas pertenecen.

La solución federal, que pareceria desprenderse como corolario lógico de tales postulados, será, no obstante, rechazada. No se trata tan sólo de que traiga malos recuerdos a los viejos republicanos, marcados aún por la desgraciada experiencia cantonalista. Tampoco es este rechazo fruto del convencimiento de que las fuerzas económicas empujan al mundo hacia una creciente unificación. En realidad lo que subyace bajo el rechazo a la fórmula federal es el temor, mal disimulado, a que abra paso a la disgregación del Estado. Por ello se aceptará como válido para aquellos estados que han nacido de la integración de territorios con personalidad política preexistente caso de Alemania, Suiza o los Estados Unidos- pero se considera inadecuado para el caso de una Nación como España, que lleva cinco siglos de unidad.

La autonomía será en consecuencia, la única solución válida. Pero debemos matizar el concepto de autonomía de los melquiadistas. En primer lugar, no debe pensarse que la autonomía es la receta adecuada para todas las regiones; debe aplicarse tan sólo a aquéllas que la necesiten y se muestren capaces de asumirla. Se trata, por tanto, de una fórmula específica pensada para ser aplicada al problema catalán y vasco, no de un modelo de Estado. $Y$ no es que el PRLD se muestre precisamente comprensivo con los nacionalismos; en el fondo tiende a ver en ellos un deseo encubierto de separatismo peligroso para la unidad nacional. Por ello son frecuentes los alegatos antinacionalistas en la prensa afín al partido. Los argumentos utilizados son variados. Se afirma, por una parte, que la existencia de fuertes poderes regionales, como desean los nacionalistas catalanes o vascos, supone un riesgo para la libertad de los ciudadanos, pues al debilitar aquéllos al Estado quedarán éstos inermes ante los poderes impersonales que la economía capitalista va fortaleciendo día a dia:

La libertad de trabajo y de asociación dió lugar a la formación de grandes sociedades industriales, que para satisfacer exageradas ambiciones propenden al abuso y al atropello de la libertad, para luchar contra las cuales necesita el individuo la protección de un Estado central. Otro grave peligro para la libertad está en la creciente fuerza de los sindicatos, que asimismo tienden a abolir la personalidad individual, para cuya defensa se precisa también la mano poderosa de un Estado unitario ${ }^{40}$.

ai) Estas palabras pertenecen a Alfredo Martínez, jefe del partido en Asturias y uno de los requeridos para enviar sus opiniones a El Noroeste, que las publica, junto a las de los demás 
En otras palabras: la civilización moderna, como resultado de la propia democracia y de los derechos que ésta concede a los ciudadanos, está creando poderosas organizaciones cuya acción en favor de intereses concretos puede acabar por cercenar los mismos derechos que les han dado la vida. Un Estado débil y fragmentado sería débil muro contra tales concentraciones de poder; sólo un Estado fuerte - aunque no necesariamente centralizado- podría hacer frente a esos nuevos poderes creados por la sociedad moderna.

También la economía aportará argumentos. Un cierto resabio del viejo principio liberal del umbral ${ }^{41}$ parece subyacer en la apelación a la creciente integración económica mundial, que exige mercados cada vez más grandes y condena a la pobreza y al atraso, se dice, a los países pequeños. La difusión de una identificación más o menos explícita entre autonomía de ciertas regiones y perjuicios económicos para las que no la alcancen será también explotada con considerable frecuencia desde la prensa y los mítines.

Otros argumentos son de índole cultural. El supuesto peligro para lengua castellana, por su capacidad de movilización emocional, será el más utilizado.

¿Cómo ha de cumplir la misma finalidad un dialecto que to entienden cuanto más unos miles de almas, que un lenguaje casi universal como el castellano?

En buena hora los dialectos, para todo lo afectivo, para todo cortejo de dicha ilusoria o imaginaria, intima, familiar, pero ¿cómo anteponerlos al idioma de Cervantes...? ${ }^{42}$

Tales argumentos ayudan a comprender el carácter limitado de la autonomía que los melquiadistas están dispuestos a conceder a catalanes y vascos. No se trata en ningún momento de una autonomía política que lleve aparejada la capacidad de aprobar leyes sobre las competencias transferidas por el Estado; se piensa en una autonomía limitada a lo administrativo, a la mera aplicación de las leyes aprobadas por el Parlamento

candidatos de junio, bajo el título de "Los candidatos a diputados del Partido Republicano Liberal Demócrata hablan de los lectores de El Noroeste", 15 de agosto de 1931.

${ }^{41}$ Según este principio, sostenido por los tratadistas liberales del XIX, no tenía sentido defender la independencia de regiones que no fueran lo bastante grandes como para ser económicamente viables. Puede encontrarse una explicación más completa de este principio en HoBsBawm, E.: Naciones y nacionalismo desde 1780, Barcelona, Crítica, 1991, págs. 40 y ss.

42 Cuber, M:: "SOBRe El ACtO DEL PALACE. Melquiades Álvarez (IV)". El Noroeste, 9 de junio de 1931 
de Madrid, único depositario de la soberanía nacional. Tal es el contenido que uno de los padres del reformismo, Azcárate, atribuía a un vocablo por él acuñado como resumen de la postura del partido sobre este tema: la autorquía, que venía a nombrar la facultad de regirse y gobernarse a si mismo dentro de la ley ${ }^{43}$. Melquiades Álvarez lo confirmaba en un discurso pronunciado en Mora de Toledo en mayo de 1932: ...la autonomía no es la segregación. No consiste en arrebatar las facultades inherentes a la soberanía del estado para transmitirlas a personalidades históricas efímeras. Estas facultades son inalienables. No pueden cederse ${ }^{44}$. No es extraño, desde estas posturas, el absoluto rechazo y la fuerte campaña con que el PRLD recibe el Estatuto de Cataluña desde el momento en que comienza su discusión en las Cortes. Incluso una autonomía más bien moderada como la que se le concedió a Cataluña en 1933 era demasiado para un partido cuya tradición liberal y jacobina pesaba más que la necesidad de adecuarla a las demandas concretas planteadas por la realidad del momento.

La cuestión religiosa era otra de las fundamentales, o al menos de las que los gobiernos del primer bienio transformaron en fundamentales. Ya hemos visto más arriba cual era la sensibilidad melquiadista ante el tema, de modo que nos limitaremos aquí a recoger la vertiente práctica de esas ideas. La separación entre la Iglesia y el Estado será la solución suficiente para el problema, pero no debe ser inmediata, sino precedida de un largo período de adaptación que cumplirá la doble función de tranquilizar las conciencias y de privar a la Iglesia de su capacidad de convertirlas en fuerza peligrosa para la democracia. Durante ese período, la Iglesia estará sometida al control del Estado, que velará porque su actividad no atente contra los derechos individuales. Por lo demás, será libre para desarrollar su función religiosa, así como cualquier otra actividad permitida a los ciudadanos: enseñar, producir y comerciar. Las órdenes religiosas, en consecuencia, serán respetadas, pero sometidas también a control estatal. Los cultos serán libres en todo aquello que no atente contra la moral pública y el Estado quedará dueño absoluto de las competencias que le son propias: matrimonio civil, nacimiento, defunción, enterramiento, enseñanza...

Como instrumento jurídico que sancione y dé permanencia a tales medidas, el partido defiende el concordato, que presenta como ventaja suprema la superación de las tensiones que pudieran surgir con la jerarquía

43 Cuber, M.: Melquiades Álvarez... pág. 208

44 Editorial sin titulo, El Noroeste, 4 de mayo de 1932. 
eclesiástica y, en consecuencia, facilita su asimilación por los fieles. Una solución como la dada al problema por las Cortes Constituyentes, en consecuencia, no puede ser bien recibida por los melquiadistas. Primero, porque un partido de convicciones liberales no puede aceptar que se limiten los derechos fundamentales de los ciudadanos, y los miembros del clero son ciudadanos que no han cometido delito alguno. La apelación a la razón de Estado para justificar las medidas aplicadas resulta, claro está, inadmisible, simplemente porque un gobierno de sentido opuesto podría recurrir a idéntico argumento para aplicar una política clerical y persecutoria con el libre pensamiento. Segundo: porque hace caso omiso de los sentimientos probados por una buena parte del país, arrojando a un gran porcentaje de la opinión pública fuera del régimen y dificultando con ello su consolidación, sólo por ceder a un inconfesable afán demagógico y aun a riesgo de provocar con ello la guerra civil, olvidando lo absurdo que resulta intentar arrancar por la fuerza de las leyes lo que corresponde al mundo de los sentimientos y las creencias. Tercero: porque supone la atribución por el Estado de monopolios que sólo los totalitarios reivindican, como la enseñanza, y que jamás pueden convertirse en atribución exclusiva del poder público en un Estado democrático.

$Y$ es que, en efecto, el tema de la enseñanza mantiene aún fuertes vinculaciones con la cuestión religiosa en la España de los treinta. Por inoperancia o incapacidad del Estado liberal, las instituciones escolares de las órdenes religiosas se habían convertido en una pieza fundamental del sistema docente, sobre todo en lo que se refiere a la enseñanza secundaria, y dada la discrepancia entre los valores defendidos por la Iglesia Católica y los que inspiraban el nuevo régimen, no es raro que para muchos republicanos construcción masiva de establecimientos docentes estatales y prohibición de enseñar a la Iglesia hubieran de marchar juntos.

No opina así, por el contrario, como hemos visto, el PRLD. La enseñanza obligatoria, competencia del Estado, debe compaginarse con la libertad de enseñanza. La primera consolida la República y la democracia misma al transformar a las masas populares incultas $y$ analfabetas $-y$, por ende, manipulables - en ciudadanos conscientes de sus derechos y responsabilidades. Pero es más que eso; es el instrumento básico para la modernización y el progreso del país, el medio sin el cual el resto de las reformas se convertirán en papel mojado. La raíz krausista del reformismo melquiadista sigue siendo en esto tan evidente como siempre. Pero si esto es así, no es menos cierto que la enseñanza obligatoria estatal no es incompatible con el derecho incuestionable de los ciudadanos a elegir el tipo de valores que desean que les sean transmitidos a sus hijos. La escuela es continuación de la familia y el Estado no puede atribuirse el 
monopolio de competencias que afectan al terreno de la familia y las creencias. Por ello la libertad de enseñanza debe estar garantizada.

¿Pero no se aprovecharán las órdenes religiosas de ese derecho que ampara a todos los ciudadanos para difundir desde sus aulas valores y principios peligrosos para la República y la democracia? Naturalmente, existe ese riesgo. Para evitarlo, el Estado, que se reserva, eso sí, la función de la suprema inspección, de la definición de los programas y de la colación de grados, ejercerá un control continuo sobre la enseñanza en los centros privados, con el fin de evitar que la enseñanza religiosa sea un disfraz que oculte la difusión de ideales antidemocráticos. No podrá, no obstante, imponer en ellos el laicismo, porque tal imposición conculcaría el derecho a profesar y difundir libremente cualquier religión. Sólo, por tanto, será laica la enseñanza pública, pues un Estado sin religión oficial no puede dar en sus centros docentes una enseñanza inspirada en una opción religiosa determinada, sino una instrucción antidogmática, ajena a la mera transmisión acrítica de doctrinas, basada en el cultivo de la libertad de pensamiento y de opción.

Existe, además, una razón práctica para apoyar la pervivencia de las instituciones docentes de la órdenes religiosas: el Estado español es pobre aún; carece desde luego de los recursos necesarios para sustituir por sí mismo la enseñanza que se imparte en los centros de la Iglesia. La supresión inmediata de estos, por tanto, sólo traería el caos, la expulsión de las aulas de miles de alumnos que se verían privados de enseñanza alguna. Como señala, indignado, Cuber, ¿No hubiera sido mejor haber creado todas las escuelas laicas que el Estado estimase necesarias, pero respetando las que ya hubiese establecidas, para los que quisieran utilizarlas? ¿No es una demencia suprimir centros de enseñanza, sea de la clase que sean, en un Nación como España, en la que la mitad de la población escolar carece de albergue y de maestros? ${ }^{45}$.

¿Se adecuó a este programa la labor del liberal demócrata Villalobos como Ministro de Instrucción Pública en algunos de los gobiernos del segundo bienio? No resulta fácil juzgarlo, dado que al tratarse de gobiernos de coalición fuertemente dependientes del apoyo de la más conservadora y clerical CEDA en el parlamento, no contaba el ministro salmantino con la libertad de maniobra suficiente. Si se puede asegurar que continuó con energía la tarea de impulsar las construcciones escolares y elevó los salarios del magisterio nacional, pero también que contravino el programa del 
partido en lo referente al Bachillerato, cuya reforma impulsó bajo unos criterios bien distintos: la eliminación de los exámenes por asignaturas, la introducción de un programa unitario y el excesivo número de disciplinas ${ }^{46}$.

Otras cuestiones merecen mucha menor atención en el programa del PRLD. Algunas, ni siquiera se tratan en ningún momento, como la política exterior, sobre la cual apenas podemos hacer especulaciones en torno a la posición del partido. Debemos, pues, suponer que su postura no se había apartado en lo esencial de la que había sido tradicional en el reformismo: la adhesión a los principios wilsonianos que habian llevado a la creación de la Sociedad de Naciones, y el alineamiento con la política exterior de Francia y Gran Bretaña, las potencias que representaban en Europa la esencia de los principios liberales y democráticos con los que el melquiadismo se identificaba, pero sin abandonar la neutralidad en los enfrentamientos internacionales que pudieran surgir, dado que a España, país débil militarmente, le interesaba más que a nadie la conversión en hecho positivo de los principios de la SDN ("Comentarios. Días solemnes", por Isidoro Millán, en El Noroeste, 3-10-35). Otras se tratan tan sólo de modo superficial, como la cuestión militar, acerca de la cual los pronunciamientos de los líderes melquiadistas no abundan pero son lo bastante significativos para permitirnos deducir un acuerdo básico con la izquierda en cuanto al diagnóstico de los males que afectan al ejército, aunque compaginados con su total exculpación de sus fracasos históricos y con la insistencia en la necesidad de fortalecerlo ${ }^{47}$.

Más importancia atribuye el melquiadismo a un tema en apariencia secundario como es la justicia, aunque esto no debe extrañarnos en un partido que hace de la defensa a ultranza de los derechos individuales una de sus señas de identidad. En efecto, la independencia del poder judicial es, en el pensamiento de los liberal demócratas, uno de los pilares de la democracia, hasta tal punto de que por encima de él, en lo tocante a la aplicación de las leyes, no deben estar ni siquiera las Cortes. Las medidas legislativas de excepción, tendentes a recortar la independencia judicial en favor del ejecutivo no pueden, por tanto, ser bien vistas, lo que conducirá al PRLD a rechazar leyes supuestamente concebidas para proteger la democracia como la de Defensa de la República. El substrato liberal brilla con luz propia en este rechazo de la flagrante contradicción que supone el

\footnotetext{
46 Para una mayor profundización en esta contradicción, puede verse la obra de RODRIGUEZ DE LAS HERAS, A.: Filiberto Villalobos. Salamanca, Centro de Estudios Salmantinos, 1985.

47 Véase a este respecto CUBER, M.: Melquiades Álvarez... págs. 260-268 y del mismo autor, "Sobre el acto del Palace...". El Noroeste, 9 de junio de 1931.
} 
recurso a medios antidemocráticos para lograr fines democráticos. Pero no es menor aquella en la que incurre el melquiadismo al rechazar el juicio por jurado apelando a la falta de experiencia y la supuesta venalidad de los legos en leyes; al defender la pena de muerte como mejor garantía para apartarse de la impunidad del delito, o, en fin, al huir de concesión alguna a toda finalidad de reinserción social del sistema penitenciario, cuya función no debe ir, a decir de los liberal-demócratas, más allá de la simple amputación del cuerpo social de sus elementos podridos. Sólo una voz se eleva como nota discordante en este recital de conservadurismo liberal, la del doctor Villalobos, que llega a rechazar la posibilidad de entrar como Ministro de Justicia en el gobierno Samper por haberse aprobado poco antes de su constitución, el 27 de marzo de 1934, la pena de muerte para los delitos de terrorismo ${ }^{48}$.

\section{¿UN PARTIDO DE DERECHAS?}

Esperamos con esto haber ofrecido una visión lo más completa posible de las posiciones ideológicas y programáticas del PRLD durante la Segunda República. Pasamos ahora a la ardua tarea de intentar, a partir de ellas, ubicar a dicha fuerza en el espectro político del régimen, lo que, a su vez, supone la necesidad de explicitar unos criterios de clasificación, siquiera generales, susceptibles de ser aplicados al conjunto de los partidos de la época.

Entendemos que las fuerzas políticas españolas en el contexto de la Segunda República se presentaban en la práctica divididas en función de su posicionamiento con respecto a tres cuestiones fundamentales: la social, la religiosa y la que se refiere a la forma del Estado. El resto de los temas, o pueden ser de algún modo reducidos a una de estas cuestiones, como es el caso del problema agrario, susceptible de ser comprendido satisfactoriamente como plasmación en el campo de la cuestión social, o no marcan, en nuestra opinión, líneas de diferenciación lo bastante claras como para posibilitar una clasificación. No pretendemos, como es evidente, un tratamiento exhaustivo ni definitivo del problema, sino tan sólo llegar a una primera conclusión a partir de los temas tratados, que más adelante y en

\footnotetext{
${ }_{48}$ Para una mayor profundización en el programa de Justicia del PRLD véase CUBER, M. Melquiades Álvarez..., págs. 213-230. Es también interesante conocer de primera mano la postura del propio Álvarez, que la sintetizó con gran claridad en un discurso pronunciado en las Cortes en abril de 1932 (en El Noroeste, 30 de abril de 1932).
} 
nuestro trabajo de investigación global sobre el melquiadismo -en cursointentaremos confirmar o matizar con mayor apoyo documental.

De acuerdo con los criterios elegidos, podríamos decir que la derecha española de los años treinta es, en general, corporativista en lo social, autoritaria, antiparlamentaria y centralista, en mayor o menor grado, en lo político, y confesional en lo religioso. Por el contrario, la izquierda burguesa se nos presenta liberal, aunque en tránsito hacia un moderado intervencionismo, en lo social; democrática, parlamentaria y descentralizadora en lo político, y extremadamente laica, casi anticlerical, en lo religioso. Naturalmente, los partidos y sindicatos obreros formarían una izquierda diferente, aunque laica, socialista y sólo instrumentalmente democrática y parlamentaria en su mayoría, y por tanto no asimilable a los partidos burgueses progresistas. Se trata, además, de una realidad dinámica, nunca de una foto fija. En líneas generales, se puede decir que ambos extremos del espectro político tienden a la radicalización: la derecha se vuelve cada vez más autoritaria, corporativa y antiparlamentaria; la izquierda obrera tiende a adoptar, siquiera verbalmente, posturas cada vez más revolucionarias; ambas, en último extremo, acaban apostando por soluciones violentas ajenas ya al conflicto político propiamente dicho.

¿Cómo clasificar, pues, al Partido Republicano Liberal Demócrata de acuerdo con estos criterios? Como hemos visto, se trata de una fuerza política cuyos orígenes históricos hay que buscar en el patrimonio cultural, ideológico e incluso axiológico propio de los republicanos. Un patrimonio, por tanto, común a todo el republicanismo excepto, naturalmente, al nacido de la especial coyuntura de 1930, y compartido, en consecuencia, con lo que hemos llamado izquierda burguesa. No obstante, resulta evidente lo inadecuado de clasificar al melquiadismo entre las fuerzas de la izquierda. En primer lugar, si sus orígenes históricos eran republicanos, y su herencia cultural de inequívoco cuño krausista, su táctica peculiar, aplicada durante casi más de una década bajo el régimen de la Restauración, le separó de ellos hasta el punto de renunciar a casi todo el programa que lo hacía ser republicano -y al mismo republicanismo-e incluso de aceptar entrar en un gobierno en cuyo origen había seguido funcionando el caciquismo. Por otra parte, si el resto del republicanismo, el que en la República formará la izquierda burguesa, ha evolucionado, no le sucede así al melquiadismo, cuyas recetas siguen siendo, con escasas variaciones, las mismas que en 1918, pero ahora para ser aplicadas a una sociedad que ha evolucionado de forma notable. Así, como los republicanos de izquierda, el melquiadismo será, en lo social, liberal, pero mientras aquellos van aceptando un papel creciente del Estado en la economía, este criticará el despilfarro del gobierno y mirará con recelo los subsidios, desconfiando de 
todo cambio demasiado rápido. Como ellos, será democrático y parlamentario, pero mientras la izquierda ha sido capaz de abandonar la carga centralista de su herencia jacobina, los liberal-demócratas no pueden aceptar una autonomía distinta de la puramente administrativa, viendo por ello en cualquier petición de autogobierno autónomo un intento encubierto de separatismo. Como la izquierda, permanece fiel al laicismo, pero en un momento en el que aquélla lo trasciende para adoptar posturas francamente anticlericales que no dejan de entrar en contradicción con su ideología democrática, el melquiadismo lo atempera y lo somete a las exigencias de su liberalismo. Por último, el mismo carácter evolucionista y moderado del partido, que le impulsa a desconfiar de los cambios en exceso acelerados, tiende a separarle de una izquierda con la que tantas cosas habia compartido.

¿Quiere esto decir que el PRLD es, en la República, un partido de derechas? Creemos que no. Las diferencias doctrinales son demasiado profundas. El liberalismo y el carácter inequivocamente democrático y parlamentario del melquiadismo lo separan de una derecha que no cree en lo que denomina democracia inórganica, ni hace de los derechos del individuo y la voluntad de la mayoría las bases del ordenamiento jurídico del Estado. Del mismo modo, el laicismo liberal-demócrata, aunque muy templado ya como reacción ante el anticlericalismo de los gobiemos social-azañistas y quizá también como respuesta a unas bases cada vez más conservadoras, no es asimilable al carácter confesional y francamente clerical que caracteriza a toda la derecha, quizá con la relativa excepción del peculiar fascismo español. Por último, el corporativismo de que hacen gala tanto cedistas como los grupos que darán origen al Bloque Nacional y la misma Falange, contrasta vivamente con el liberalismo dogmático de un partido sumamente respetuoso con la iniciativa privada y la libertad de mercado.

Naturalmente, esto sólo quiere decir que ideológicamente el melquiadismo se diferenciaba bastante de la derecha, tal como ese concepto debe ser entendido, en nuestra opinión ${ }^{49}$, en la España de los años treinta. Tácticamente, sin embargo, el acercamiento era posible y se produjo. Los factores que lo posibilitaron son múltiples y merecerían un estudio por si solos, aunque podríamos citar como fundamentales por un lado el rechazo visceral que inspiraba al Partido Liberal Demócrata, como al resto de los republicanos moderados, la presencia del socialismo en el gobierno y su

49 Para una clasificación de la derecha europea, puede consultarse el primer capítulo de la obra de Julio Gil Pecharromán Conservadores subversivos, La derecha autoritaria alfonsina (1913* 1936). Eudema, Madrid, 1994. 
incompatibilidad doctrinal con él ${ }^{50}$, y por otro, y en un proceso comparable al experimentado por el Partido Radical, la evolución progresiva de sus bases sociales -en general pequeñas burguesias cuya mentalidad política evoluciona de modo paralelo a su posición económica- hacia el conservadurismo, como ha señalado acertadamente Suárez Cortina ${ }^{51}$.

Por todo ello creemos que el PRLD podría ser definido con toda propiedad como partido de centro. Así lo prueban sus posicionamientos. Como la izquierda, desea reformas, pero, como la derecha, pretende ralentizar su aplicación porque teme por el orden social; simpatiza con las reivindicaciones obreras, pero teme que se radicalicen en exceso; hace gala de su laicismo, pero rechaza sin embargo el anticlericalismo radical de la izquierda, del mismo modo que el clericalismo trasnochado de la derecha; republicano, no cree que la República deba ser otra cosa que la quintaesencia de la democracia, con sitio para todos los españoles. En la mayoría de los temas, por tanto, el partido manifiesta una posición centrada, aunque no siempre equidistante de ambos extremos. Tal era, no obstante, su vocación, como señaló más de una vez Melquiades Alvarez:

¿De derechas? No. ¿De izquierda en el sentido en que lo entienden algunos, dando a esa palabra un valor de exaltada energía, como si los demás que no lo fueran careciesen de patriotismo, de constancia y eficacia para defender las ideas? No; tampoco. Nosotros somos un partido de conservación y de progreso social.

De conservación, porque tenemos el deber de amparar y defender sagrados intereses sociales, en cuanto estos intereses sean legitimos y respetables. De progreso social porque mediante la evolución vamos a facilitar el triunto de todas las ideas, por radicales y atrevidas que sean, siempre que estén maduras en la conciencia nacional ${ }^{52}$.

Y la propia izquierda acepta esta posición centrista del partido, consciente de que no puede meterse en el mismo saco a la derecha monárquica o criptomonárquica, clerical y corporativista, y al conservadurismo republicano, laico y moderadamente reformista que Alvarez simboliza:

Una derecha dentro de la República significa cosa muy distinta que dentro de la Monarquia. En la Monarquia una derecha puede estancarse, difi-

50 Una lectura tan sólo superficial del órgano oficioso del partido, El Noroeste de Gijón, entre diciembre de 1931 y noviembre de 1933 revela cómo el antisocialismo constituye casi la preocupación fundamental de los editoriales del periodico durante todo el primer bienio.

51 SuÁrez Cortina, M.: "Melquiades Álvarez...", págs. 33-34.

52. El Noroeste, 26 de mayo de 1931. 
cultar el progreso social y politico, incluso revertirlo y ser reaccionaria. En la República, ni siquiera una derecha puede ser reaccionaria, sino que ha de seguir la norma que a su partido trazaba el señor Álvarez: no ser obstáculo a ninguna reforma que esté en sazón. Cuando se oye a algunos republicanos de derecha oponer un veto rotundo a ciertas posibles reformas, es que en ellos permanece el derechismo sobre el republicanismo, que aquello es lo sustantivo y esto lo adjetivo ${ }^{53}$.

\section{ESTADO DE LA CUESTIÓN}

Como ha podido quizá deducirse por lo visto hasta aquí, la reflexión historiográflca sobre el melquiadismo debería conducir, de un modo u otro, al análisis del papel que desempeñó el fracaso de las alternativas reformistas moderadas o centristas en la grave crisis que padeció España durante la segunda mitad de los años treinta. Sin embargo, y a pesar de que este tema es uno de los más trascendentales que puede plantearse la historiografía contemporánea de nuestro país, el interés que el melquiadismo ha merecido a los historiadores ha sido exiguo, por no decir secundario. Es cierto que las primeras obras acerca de Melquiades Álvarez y de su partido aparecen en fecha tan temprana como es la Segunda República. Me refiero a los libros de Antonio López Oliveros Asturias en el resurgimiento español (Madrid, 1935) y de Mariano Cuber Melquiades Álvarez. El orador, el hombre, el político, sus ideales, su consecuencia, su integridad (Madrid, 1935). En ambos casos, sin embargo, se trata de obras escritas por militantes más o menos destacados del partido. López Oliveros era el director del diario oficioso del melquiadismo en Gijón, El Noroeste, y una de sus figuras más destacadas en la ciudad asturiana. Cuber, por su parte, había sido alcalde de Valencia y subsecretario de Instrucción Pública bajo ministros liberal-demúcratas durante el segundo bienio de la República. No debe extrañar, en consecuencia, que estas obras carezcan de la necesaria objetividad, llegando a rozar incluso el puro panegírico, lo cual, si no impide obtener de ellas una valiosa información que las convierte en fuentes imprescindibles, sí las descarta por completo como obras científicas. Algo similar puede decirse sobre otro libro posterior de López Oliveros: Un tribuno español. Melquiades Álvarez, que fue publicado en Cuba en 1947.

La primera obra historiográfica más o menos seria publicada sobre el tema es la de Maximiano García Venero. Sin embargo, dado que este

5.3 "Dos temas. El discurso de Melquiades Álvarez y la política del Vaticano", Crisol, 26 de mayo de 1931. 
prolífico historiador escribió su Melquiades Álvarez. Historia de un liberal en la década de los cincuenta, no deben sorprender sus evidentes limitaciones en lo referente al método. De hecho, el libro es poco más que una biografía personal y política del líder reformista que adopta en todo momento una forma narrativa, parca en análisis y carente por completo de un mínimo estudio estructural de su partido. Las referencias que se encuentran en la obra acerca de organización, ideología, táctica, bases sociales o cualquier otro elemento de los que hoy consideramos imprescindibles en el estudio serio de una fuerza política, son escasas e inconexas. La obra, en el fondo, tiene un único y exclusivo protagonista: Melquiades Álvarez. Todo lo demás se difumina hasta convertirse en un fondo impresionista que ni siquiera cumple con mucho éxito el papel característico de las biografías de servir de contexto iluminador al personaje estudiado. A pesar de ello, la obra fue la única sobre el tema durante décadas, lo que posibilitó que viera la luz una segunda edición en los años setenta ${ }^{54}$.

Precisamente en el transcurso de esa década, un investigador norteamericano de la Universidad de Wisconsin, E. G. Gingold, realizó su tesis doctoral sobre el reformismo. Se trataba de una obra ambiciosa que analizaba su trayectoria desde sus raices, a comienzos de siglo, hasta su final, en 1936. El autor manejó todas las fuentes escritas disponibles, tanto públicas como privadas, y utilizó además las fuentes orales que por entonces, cuando aún sobrevivian algunos miembros del partido, y sobre todo sus descendientes más próximos, estaban disponibles. Contó, además, como es lógico, con la ayuda de Garcia Venero, que lo indica así en la segunda edición de su obra. A pesar de ello, la tesis de Gingold decepciona bastante. No supuso una mejora muy notable, y quizá por ello no ha merecido una traducción al castellano ${ }^{55}$. El carácter narrativo y lineal sigue siendo la nota predominante, sobre todo en la parte referida a la trayectoria del Partido Republicano Liberal Demócrata, heredero, como es sabido, del reformismo, durante la Segunda República. Pero aun así, la obra tiene algún interés por el volumen de fuentes manejadas.

Llegamos al fin al estudio más completo que se ha hecho hasta la fecha sobre el reformismo, el de Suárez Cortina: El reformismo en España ${ }^{56}$, que no es sino la versión en libro, naturalmente reducida y adaptada, de su tesis doctoral leida en la Universidad de Santander: El Partido Reformista,

\footnotetext{
Garcia Venero, M.: Melquiades Álvarez. Historia de un liberal. madrid, Tebas, 1974.

Gingold, E.G.: Melquiades Alvarez and the Reformist Party, 1901-1936. Tesis doctoral mecanografiada de la Universidad de Wisconsin, 1973.

55 Suarez Cortina, M.: El reformismo en España. Madrid, siglo xxi, 1986.
} 
1912-1931. Tiene, sin embargo, una limitación: se detiene al final de la Dictadura de Primo de Rivera, quedando fuera del estudio el interesante período de la Segunda República, durante el cual el melquiadismo llegó a aportar en sucesivas ocasiones ministros a los gabinetes de coalición del segundo bienio, no siendo, por tanto, una fuerza política ni mucho menos despreciable, por más que su momento histórico hubiera pasado ya. Otro breve trabajo del mismo autor sobre el tema puede encontrarse en el Bulletin d'Histoire Contemporaine de l'Espagne: "Melquiades Álvarez, liberal y demócrata" 57 . En él se centra Suárez Cortina en los aspectos ideológicos del reformismo y en los orígenes de su tradición doctrinal, pero sin olvidar aspectos como el estudio - breve- de sus bases sociales o el de sus apoyos en el mundo intelectual. Sigue, no obstante, sin prestar atención al período de la Segunda República. Parece que la mayor parte de los autores o no lo tratan, como es el caso que acabamos de citar, o simplemente no lo consideran susceptible de un análisis individualizado, sino mera prolongación de la trayectoria anterior del reformismo, como sucede con García Venero o Gingold, que se limitan a narrar los hechos acaecidos a aquél durante esos años.

Existe, no obstante, un estudio que sí presta especial atención a la Segunda República, el de A. Rodríguez de las Heras sobre Filiberto Villalobos, ministro liberal demócrata de Instrucción Pública durante el segundo bienio del régimen. Su título, sin embargo, da buena cuenta de las limitaciones de la obra en lo referente al tema qua nos ocupa: Filiberto Villalobos. Su obra social y política ${ }^{58}$. Se trata, en efecto, de un estudio del afamado médico y político salmantino, de sus ideas acerca de los problemas más importantes que se planteaban en el contexto social en el que creció -el campo castellano-, de sus medidas al frente del Ministerio y, de forma secundaria, de su posicion dentro del partido y de las causas de su ruptura final con el mismo. No hay, por tanto, más que una referencia colateral al melquiadismo; Villalobos es el protagonista absoluto, como lo es Álvarez en la obra de García Venero.

La conclusión que puede extraerse de esta breve análisis de las obras existentes sobre el tema es que, si bien puede considerarse suficientemente estudiada la trayectoria del reformismo bajo la Restauración, en modo alguno puede decirse lo mismo del período de la Segunda República,

57 Suarez Cortina, M.: “Melquiades Álvarez, fiberal y demócrata», Bulletin d'Histoire Contemporaine de l'Espagne, número 10, diciembre de 1989.

5. ROORIGUez de las Heras, A.: Filiberto Villalobos. Su obra social y politica. Salamanca, Centro de Estudios Salmantinos, 1985. 
al que se ha venido considerando, en lo que a la vida del partido se refiere, más bien una prolongación carente de rasgos distintivos y, en consecuencia, de interés en sí misma. La necesidad de abordar ese estudio como tema monográfico, que este artículo viene a cubrir en parte muy modesta, es, pues, evidente.

Las fuentes que pueden manejarse para ello, por desgracia, no son todo lo abundantes que sería de desear. La forma en que acabó sus días Melquiades Álvarez, asesinado en 1936, en la matanza de la Cárcel Modelo de Madrid, así como su tradicional manía de no escribir nunca nada, que el líder reformista hacía extensiva incluso a sus discursos, que siempre improvisaba, no facilitan las cosas. La prensa se erige así -mientras no sean localizados documentos internos del partido que puedan haber sobrevivido en manos de algún descendiente de sus líderes-en fuente primordial. Las publicaciones de Asturias y Salamanca, los dos baluartes del PRLD durante la República, cobran importancia central, especialmente El Noroeste, diario gijonés dirigido por López Oliveros que servía de portavoz oficioso del partido y que, en consecuencia, reproducía íntegros todos los discursos de Álvarez en cualquier lugar de España. En menor medida, La Voz de Avilés, que no fue tan constante en sus simpatías melquiadistas, y El Adelanto de Salamanca, que simpatizaba con Villalobos, son también útiles. Respecto a los diarios madrileños, los moderados como Ahora y El Liberal, no dejan de constituir referencias importantes, asi como, en mucha menor medida, dados sus cambios de orientación, El Sol. El primero de estos diarios es de obligada consulta, pues su director, Luis Montiel, formó parte, junto a Álvarez, Ossorio y Gallardo y Sánchez Guerra, en la candidatura llamada "De Apoyo a la República» por Madrid en las elecciones de junio de 1931, con lo que, como es lógico, la información sobre las elecciones y sobre las posiciones de los candidatos - no sobre la campaña de la candidatura, que fue nula - son abundantes. Para el segundo bienio, cuando los liberales demócratas apuestan ya por la alianza con radicales y cedistas y aportan ministros a los gabinetes de colación, El Debate, órgano de la derecha accidentalista católica, es también fuente de considerable interés.

En cuanto a las fuentes biliográficas, las citadas al principio tienen gran interés. Las obras de López Oliveros son útiles para abordar un estudio detallado de la trayectoria de Álvarez, aunque no se limitan al período de la Segunda República. La de Mariano Cuber, por su parte, a pesar de su carácter reiterativo y su nula calidad literaria, proporciona una información notable acerca del programa y la ideología del partido, aunque esté ya escrita en un momento en el que éste había sufrido ya una considerable derechización, siquiera táctica. Otras obras, como las de Tusell sobre las 
elecciones de 1931 y 1936, la de Girón Garrote sobre elecciones y partidos políticos en Asturias, o la de Martín Vasallo sobre las consultas electorales en Salamanca ${ }^{59}$, resultan también de gran utilidad, así como, por supuesto, las memorias de los principales personajes relacionados de un modo u otro con Álvarez. Gil Robles, Chapaprieta, Alcalá Zamora, Lerroux, Martínez Barrio... Las referencias son, es cierto, escasas, pero la necesidad de tenerlas en cuenta es evidente, tanto más al abordar un estudio en el que, como puede verse, la importancia del tema contrasta con la parquedad de las fuentes disponibles hasta la fecha.

59 Las obras citadas son las siguientes: TUSELL, J.: Sociologia electoral de Madrid, 19031931. Madrid, EDICUSA, 1969; La Segunda Repüblica en Madrid, elecciones y partidos politicos. Madrid, Taurus, 1970; Las constituyentes de 1931, unas elecciones de transicion. Madrid CIS, 1982, y Las elecciones del Frente Popular, Madrid, EDICUSA, 1971; MARtin VASALlo, J.M.: Las elecciones a Cortes en la ciudad de Salamanca. Ayuntamiento de Salamanca, 1982, y GiRoN GARROTE, J.: Elecciones y partidos politicos en Asturias, 1890-1936. Tesis mecanografiada de la Universidad de Oviedo. 